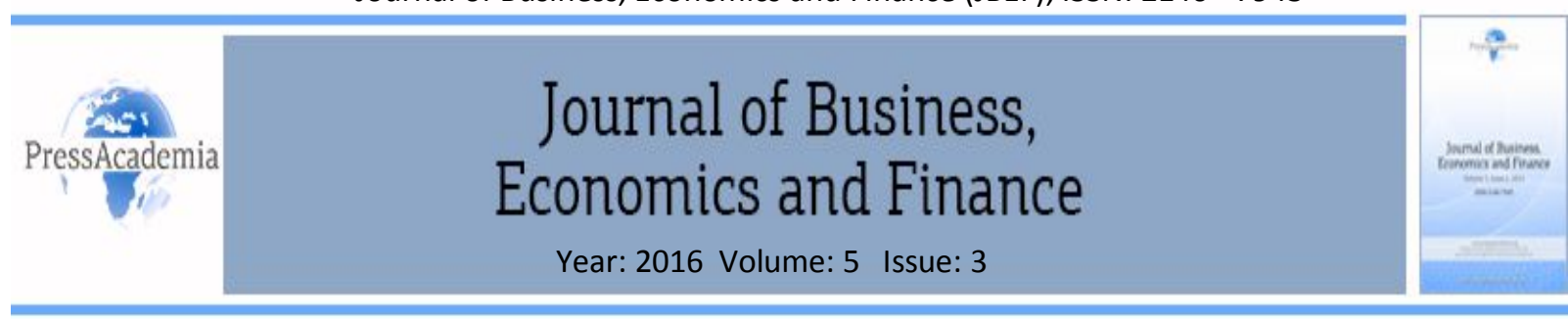

\title{
THE DYNAMIC INTERACTIONS OF WORLD NATURAL GAS MARKETS *
}

\section{DOI: 10.17261/Pressacademia.2016321971}

\author{
Ayhan Kapusuzoglu ${ }^{1}$, Xi Liang ${ }^{2}$, Merve Karacaer Ulusoy ${ }^{3}$ \\ ${ }^{1}$ Yildirim Beyazit University, akapusuzoglu@ybu.edu.tr \\ ${ }^{2}$ University of Edinburgh, xi.liang@ed.ac.uk \\ ${ }^{3}$ Yildirim Beyazit University, karacaer@ybusm.info
}

\begin{abstract}
The aim of this study is to analyse the short and long-term interactions between the natural gas markets in the context of Europe, Japan and the US that are the main constituents of natural gas consumption in the world and between the natural gas and oil markets. Within the framework of this study co-integration test is performed and the variable groups that have long-term relationships with each other are presented. Finally, the pairwise Granger causality test is performed in order to examine the short-term causality relationships and the results of uni-directional, bi-directional and non-casual relationships are found.
\end{abstract}

Keywords: energy market, natural gas, liberalization, cointegration, causality

JEL Classification: C10, F14, L95

\section{INTRODUCTION}

There are many energy sources in the world, besides their allocation and consumption are not well matched with each other. While some of the energy sources are consumed where they are produced, some are being shipped to remote areas. Natural gas is believed to be the most important energy source in meeting the global energy demand for the near future. The shipment of gas is carried out by the liquefied natural gas (LNG) form at -260 degrees Fahrenheit through pipelines to a liquefaction facility, which is generally located next to a port or railhead. After the liquefaction process, LNG can be loaded to a ship or a railroad car and carried to the facility destination at which it will re-gasified and shipped to the required destination through pipelines. In other words, LNG provides the transportation of natural gas. Barnes and Bosworth (2015) questioned whether the integration of global natural markets has increased as the trade of LNG has increased because of the decreasing transportation costs. The authors found that the increase in LNG trade plays a significant role on the increase of the integration of global natural gas markets. With the usage of LNG, the restriction on the trade between global natural gas markets started to decrease. As a result it became very important to deliver transfer LNG to multiple countries in order to increase the natural gas integration. When compared with traditional compressed natural gas (CNG), LNG has multiple delivery points and provides flexibility in gas shipments.

International Energy Agency points out that when compared with other energy sources, natural gas is friendlier with the environment, energy supply diversification is more efficient, and storage is easier and safer, cheaper and cleaner than gasoline and produces less greenhouse emissions. There are three main regional gas markets; OECD Europe, North America and Japan/South Korea. The natural gas import trade among them is as follows:

\footnotetext{
* This study was orally presented at The 5th Multinational Energy and Value Conference held between 7th-9th May 2015, Istanbul, Turkey and only the abstract was published in the conference booklet.
} 
Europe is mainly importing from Norway, Russia and Algeria, North America is mainly importing from Canada and Mexico and Japan/South Korea is mainly importing from Indonesia, Australia, Malaysia and the Middle East. As the pipeline infrastructure and LNG shipment capacity are limited. In order to understand the dynamic interactions of natural gas prices in Europe, Japan and United States first of all the geographic, infrastructure and the market conditions of these three countries should be examined. The law of one price suggests that in a perfectly competitive market two identical goods should have the identical prices but the natural gas prices differ in the market. Natural gas prices can be affected due the specific supply and transportation costs, demand, weather and geographical conditions and diversification of import. Furthermore, because the supply of natural gas is limited with specific countries, a possibility of political risk may also affect the gas prices segmentation (Siliverstovs et al., 2005).

To start with European natural gas market structure, according to U.S. Energy Information Administration (http://www.eia.gov/todayinenergy/detail.cfm?id=15411) all EU members beside Turkey, Norway, Switzerland and the non-EU Balkan states, in 2013 30\% of the totally natural gas consumption $30 \%$ of it was supplied by Russia. In addition to Russia, the natural gas imported to Europe is provided by Central Asia, the Middle East and Africa. EIA estimates that in 2030 Europe will have a dependency of more than $80 \%$ on natural gas import as its own reserves have decreased. Algerian gas serves to southern Europe whereas Norway and Netherlands serve to northern. Russian gas dominates in Germany and Italy where there is no LNG capacity beside Spain is the one with the biggest LNG consumer in Europe. Depending on this information, it is clear that Europe gas import depends on non-European gas and the gas infrastructure is needed to be expanded by installing new pipelines and LNG facilitates (Renour-Maissant, 2012). According to U.S. Energy Information Administration (http://www.eia.gov/countries/cab.cfm?fips=JA), Japan is the world's largest LNG importer with $37 \%$ of global purchase since 2012 beside its natural gas pipeline transmission infrastructure is not enough to meet this demand. The geographical location in which it is surrounded by mountains which restricts the pipeline system and the past regulation system in which the government restricted the investment for the sector can be shown as the main reasons. Mainly after the Fukushima disaster, Japan has turned its way to LNG in order to compensate the lost nuclear energy generation. Furthermore, Japan considers about the environmental factors, as a result in the reduction of greenhouse emissions natural gas seems to be the cleanest fossil fuel for Japanese. The prices of Asian LNG that depend on global crude oil prices have increased as a result of high demand of Japanese natural gas especially after Fukushima and the high crude oil prices until the middle of 2014. The recent decline in oil prices will seem to have a positive effect on Japanese revenues, which have been lower.

Natural gas market of United States is a big market with high number of suppliers, production capability and pipeline network inside. Recently, unconventional gas started to take place in the market, which has three types; shale gas, coal seam gas and tight gas. The major natural gas resources of the world are in the form of shale gas. The geographic distribution of shale gas is very important for the global energy sector. North America, South America, South Africa, Europe, Middle Asia and Arabia all have shale gas but for the United States shale gas seems to provide energy independency. The rest of the paper is organized as follows: Data and empirical methodology is given in the next section. Section 3 provides a summary statistics of the empirical findings. The paper ends with the conclusions and implications.

\section{DATA AND METHODOLOGY}

This paper investigates the short and long-term interactions among European, Japan and the United States natural gas markets and between the natural gas and oil markets. The methodology part is based on the study of Siliverstovs et al. (2005). The data covers the period of February 2000 to December 2010, totally 131 observations. For the empirical analysis, the data on energy prices are collected from the data book of Energy Prices and Taxes Statistics, which is published by International Energy Agency (IEA) in quarterly periods and the related databases are reached from OECD iLibrary (http://www.oecd-ilibrary.org/). These data are composed of average import prices within the context of Europe (Pipeline Gas and Liquefied Natural Gas/LNG), Japan (LNG) and the United States (Pipeline Gas and LNG), the average Henry Hub spot prices that reflect the natural gas spot prices along with Brent and West Texas Intermediate crude oil average spot prices that are taken as a benchmark for international oil prices. 
First of all, in order to have compatibility among different prices, gas prices are converted into US\$ per MBtu by IEA, using average conversion factors and oil prices are converted into US\$/MBtu using the standard conversion factor (1bbl crude=5.46 MBtu). In the next step, unit root tests (Augmented Dickey Fuller, Phillips Peron and Kwiatkowski-Phillips-Schmidt-Shin) are applied in order to examine the stability series. According to Augmented Dickey Fuller (ADF) test, the first difference of the variable is that it is regressed on its own delayed value and the delayed values of its first differences and hence it is tested whether ADF coefficient is zero or not (Dickey and Fuller, 1979). Another unit root test made for the determination of stability is called Phillips-Perron (PP). The distribution theory on which Dickey-Fuller tests are based on assumes that the errors are statistically independent and have a fixed variance. Phillips-Perron (1988) approach allows loosening these assumptions relating to the distribution of errors (Enders, 1995). If the series of the variables are both integrated of the same order, the presence of a long-term relationship (co-integration vector) is investigated by using the cointegration test developed by Johansen $(1988 ; 1991)$ and Johansen and Juselius (1990). Co-integration implies that there is a causal relationship between the variables but it does not reveal the direction of it. In the case of detection of a relation of co-integration that indicates the existence of a long-term relation between the variables, relations of Granger (1969) causality must be analyzed.

\section{FINDINGS AND DISCUSSIONS}

The results of ADF and PP unit root tests are presented in Appendix 1-2. The null hypothesis for the ADF and PP tests is that the variable has a unit root and is not stationary. All of the results indicate that the variables are non-stationary in level I (0), on the other hand the price series are stationary, I (1) when their first differences are taken. Findings of ADF unit root test are also supported by the findings of PP test. Once the unit root test results show that all variables are integrated at first level I (1), tests for co-integration can be applied. Appendix 3 reveals Johansen co-integration test results as determined by the Max-Eigenvalue and trace methods which examine the presence of a long-term co-integration relationship among European, Japan and the United States natural gas markets and between the natural gas and oil markets. The results display that there exists two-way co-integration vector between Henry Hub-Pipe US and Pipe Europe-Henry Hub whereas a single co-integration vector between Brent-LNG Europe, WTI oil-LNG Europe, WTI-Pipe Europe, Pipe US- LNG Europe, Pipe Europe-LNG Europe and Pipe Europe-Brent. There is no long-run relationship among other variables. Both the results of trace statistic and maximum eigenvalue support each other.

These results reveal that there is regional gas market integration in United States as the null hypothesis of no co-integration between Henry Hub spot prices and pipeline gas import prices is rejected with $1 \%$ significance level supporting the results of De Vany and Walls (1993), Serletis and Herbert (1999) and Siliverstovs et al. (2005). Moreover, there is a regional market integration in Europe, as the null hypothesis of no co-integration between LNG Europe and Pipe Europe is rejected with 1\% significance level supporting the results of Asche et al. (2011, 2002), Siliverstovs et al. (2005) and Renour-Maissant (2012). It is found that there is a strong evidence of co-integration between the price of Brent oil and each of the European gas prices and between the price of WTI oil and each of the European gas prices at $1 \%$ significance level. Differently from the results of Siliverstovs (2005) and the multidimensional scaling analysis, the null hypothesis of no co-integration between European and Japanese gas markets is not rejected. Having found evidence of a co-integrating relationship, this implies causality in at least one direction. This paper evaluates Granger causality through a pairwise Granger causality test as short-run causality. From Appendix 4, it is deduced that there is a bi-directional causality between the Henry Hub-Pipe US, LNG Japan-LNG Europe and LNG Japan-Brent oil. Moreover, there is a unidirectional causality running from Henry Hub to LNG Europe, LNG Japan and Pipe Europe, from Brent oil to Pipe US, LNG Europe, LNG Japan and Pipe Europe, from WTI oil to LNG Europe, LNG Japan and Pipe Europe, from LNG Japan to Pipe US and Pipe Europe and lastly from Pipe US to Pipe Europe. There is no causal relationship between Brent-Henry Hub, WTI-Henry Hub and WTI-Pipe US.

\section{CONCLUSION}

This study analyzed the short and long-term interactions among the natural gas markets in the context of Europe, Japan and the United States that are the main constituents of natural gas consumption in the world and between the natural gas and oil markets covering the period from 2000.02 to 2010.12. The question of 
whether natural gas markets are integrated with liberalization is important for many researches as many industrialized countries are trying to liberalize their natural gas markets by giving permission to third party access to infrastructure, reducing trading barriers and introducing privatization in order to increase efficiency and decrease prices. Considering the findings, the results of this study demonstrate that the interaction of natural gas markets within the inter-continental area is limited, whereas the natural gas markets of continental countries are liberalized that is consistent with the results of De Vany and Walls (1993), Serletis and Herbert (1999) for North America, Asche et al. (2011, 2002), and Renour-Maissant (2012) for Europe. Moreover, the study of Siliverstovs et al. (2005) is the first that regards the degree of natural gas market integration internationally and the findings of this study support them.

\section{REFERENCES}

Asche, F., Osmundsen, P., \& Tveteras, R. 2001, "Market integration for natural gas in Europe". International Journal of Global Energy Issues, 16:300-312.

Asche, F., Osmundsen, P., \& Tveteras, R. 2002, "European market integration for gas? Volume flexibility and political risk". Energy Economics, 24(3):249-265.

Barnes, R. \& Bosworth, R. 2015, "LNG is linking regional natural gas markets: Evidence from the gravity model". Energy Economics, 47:1117 .

De Vany, A. \& Walls, W. D. 1993, "Pipeline access and market integration in the natural gas industry: Evidence from cointegration tests". The Energy Journal, 14(4):1-19.

Dickey, D. A \& Fuller, W. A. 1979, "Distribution of the estimators for autoregressive time series with a unit root". Journal of American Statistical Society, 75:427-431.

Enders, W. 1995, “Applied Econometric Time Series”. New York: Wiley.

Granger, C. W. J. 1969, “Investigating causal relations by econometric models and cross-spectral methods”. Econometrica, 37:424-438.

Johansen, S. 1988, "Statistical analysis of cointegration vectors". Journal of Economic Dynamics and Control, 12:231-254.

Johansen, S. \& Juselius, K. 1990, "Maximum likelihood estimation and inferences on co-integration with application to the demand for money". Oxford Bulletin of Economics and Statistics, 52:169-210.

Johansen, S. 1991, "Estimation and hypothesis testing of cointegration vectors in Gaussian vector autoregressive models". Econometrica, 59:1551-1580

Phillips, P. C. B. \& Perron, P. 1988, “Testing for a unit root in time series regressions". Biometrica, 75:335-346.

Renour-Maissant, P. 2012, "Toward the integration of European natural gas markets: A time-varying approach". Energy Policy, 1:779-790.

Serletis, A. \& Herbert, J. 1999, “The message in North American energy prices". Energy Economics, 21:471-483.

Siliverstovs, B., L'Hegaret, G., Neumann, A. \& von Hirschhausen, C. 2005, "International market integration for natural gas? A cointegration analysis of prices in Europe, North America and Japan". Energy Economics, 27:603-615. 
Appendix 1: Augmented Dickey Fuller (ADF) Unit Root Test Results

\begin{tabular}{|c|c|c|c|c|}
\hline \multirow{2}{*}{ Variable } & \multicolumn{2}{|c|}{ ADF (Level) } & \multicolumn{2}{c|}{ ADF (First Difference) } \\
\cline { 2 - 5 } & Constant & Constant-Trend & Constant & Constant-Trend \\
\hline LN(BRENT) & $-1.207[1]$ & $-2.789[1]$ & $-9.641[0]^{* * *}$ & $-9.606[0]^{* * *}$ \\
& $(0.669)$ & $(0.203)$ & $(0.000)$ & $(0.000)$ \\
\hline LN(WTI) & $-1.309[1]$ & $-2.884[1]$ & $-8.669[0]^{* * *}$ & $-8.637[0]^{* * *}$ \\
& $(0.623)$ & $(0.171)$ & $(0.000)$ & $(0.000)$ \\
\hline LN(HENRY HUB) & $-2.506[0]$ & $-2.320[0]$ & $-10.613[0]^{* * *}$ & $-10.632[0]^{* * *}$ \\
& $(0.116)$ & $(0.419)$ & $(0.000)$ & $(0.000)$ \\
\hline LN(PIPE EUROPE) & $-1.464[3]$ & $-2.647[3]$ & $-4.285[2]^{* * *}$ & $-4.286[2]^{* * *}$ \\
& $(0.548)$ & $(0.260)$ & $(0.0007)$ & $(0.0045)$ \\
\hline LN(LNG EUROPE) & $-1.481[0]$ & $-2.012[0]$ & $-9.834[0]^{* * *}$ & $-9.805[0]^{* * *}$ \\
& $(0.539)$ & $(0.588)$ & $(0.000)$ & $(0.000)$ \\
\hline LN(PIPE US) & $-2.599[0]^{*}$ & $-2.453[0]$ & $-9.832[0]^{* * *}$ & $-9.840[0]^{* * *}$ \\
& $(0.095)$ & $(0.359)$ & $(0.000)$ & $(0.000)$ \\
\hline LN(LNG US) & $-2.182[0]$ & $-2.133[0]$ & $-10.433[0]^{* * *}$ & $-10.448[0]^{* * *}$ \\
& $(0.213)$ & $(0.522)$ & $(0.000)$ & $(0.000)$ \\
\hline LN(LNG JAPAN) & $-1.041[2]$ & $-3.588[2]^{* *}$ & $-4.820[1]^{* * *}$ & $-4.822[1]^{* * *}$ \\
& $(0.737)$ & $(0.034)$ & $(0.0001)$ & $(0.0007)$ \\
\hline Critical Value 1\% & -3.481 & -4.030 & -3.481 & -4.030 \\
\hline Critical Value 5\% & -2.883 & -3.445 & -2.883 & -3.445 \\
\hline Critical Value 10\% & -2.578 & -3.147 & -2.578 & -3.147 \\
\hline
\end{tabular}

Notes: MacKinnon (1996) one-sided p-values. The optimal lag-length for the test was selected by Schwarz Information Criterion. ***, ** and $*$ denote statistical significance at $1 \%, 5 \%$ and $10 \%$ level of significance respectively.

\section{Appendix 2: Phillips-Perron (PP) Unit Root Test Results}

\begin{tabular}{|c|c|c|c|c|}
\hline \multirow{2}{*}{ Variable } & \multicolumn{2}{|c|}{ PP (Level) } & \multicolumn{2}{c|}{ PP (First Difference) } \\
\cline { 2 - 5 } & Constant & Constant-Trend & Constant & Constant-Trend \\
\hline LN(BRENT) & $-1,115[2]$ & $-2.770[3]$ & $-9.635[1]^{* * *}$ & $-9.600[1]^{* * *}$ \\
& $(0.708)$ & $(0.210)$ & $(0.000)$ & $(0.000)$ \\
\hline LN(WTI) & $-1.272[3]$ & $-2.780[4]$ & $-8.701[2]^{* * *}$ & $-8.670[2]^{* * *}$ \\
& $(0.641)$ & $(0.207)$ & $(0.000)$ & $(0.000)$ \\
\hline LN(HENRY HUB) & $-2.752[5]^{*}$ & $-2.604[5]$ & $-10.635[4]^{* * *}$ & $-10.650[4]^{* * *}$ \\
& $(0.068)$ & $(0.279)$ & $(0.000)$ & $(0.000)$ \\
\hline LN(PIPE EUROPE) & $-1.556[6]$ & $-2.083[6]$ & $-10.682[6]^{* * *}$ & $-10.711[6]^{* * *}$ \\
& $(0.501)$ & $(0.549)$ & $(0.000)$ & $(0.000)$ \\
\hline LN(LNG EUROPE) & $-1.612[5]$ & $-2.543[6]$ & $-9.964[4]^{* * *}$ & $-9.939[4]^{* * *}$ \\
& $(0.473)$ & $(0.307)$ & $(0.000)$ & $(0.000)$ \\
\hline LN(PIPE US) & $-2.846[5]^{*}$ & $-2.734[5]$ & $-9.786[3]^{* * *}$ & $-9.790[3]^{* * *}$ \\
& $(0.054)$ & $(0.224)$ & $(0.000)$ & $(0.000)$ \\
\hline LN(LNG US) & $-2.268[1]$ & $-2.256[1]$ & $-10.412[3]^{* * *}$ & $-10.422[4]^{* * *}$ \\
& $(0.183)$ & $(0.454)$ & $(0.000)$ & $(0.000)$ \\
\hline LN(LNG JAPAN) & $-0.905[7]$ & $-2.573[7]$ & $-8.282[6]^{* * *}$ & $-8.258[6]^{* * *}$ \\
& $(0.783)$ & $(0.293)$ & $(0.000)$ & $(0.000)$ \\
\hline Critical Value 1\% & -3.481 & -4.030 & -3.481 & -4.030 \\
\hline Critical Value 5\% & -2.883 & -3.444 & -2.883 & -3.445 \\
\hline Critical Value 10\% & -2.578 & -3.147 & -2.578 & -3.147 \\
\hline
\end{tabular}

Notes: MacKinnon (1996) one-sided p-values. The optimal lag-length for the test was selected by Newey-West using Bartlett Kernel . *** and $*$ denote statistical significance at $1 \%$ and $10 \%$ level of significance respectively. 


\section{Appendix 3: Johansen Co-Integration Test Results}

\begin{tabular}{|c|c|c|c|c|c|c|}
\hline Variables & Hypothesis & Eigenvalue & TraceStatistic & Prob. & $\begin{array}{c}\text { Max- } \\
\text { EigenStatistic }\end{array}$ & Prob. \\
\hline Henry Hub & $\mathrm{H}_{0}: r=0$ & 0.222 & $38.313 * * *$ & 0.000 & $31.684 * * *$ & 0.000 \\
\hline Pipe US [4] & $H_{0}: r \leq 1$ & 0.051 & $6.628 * * *$ & 0.0010 & $6.628 * * *$ & 0.0010 \\
\hline Henry Hub & $\mathrm{H}_{0}: r=0$ & 0.074 & 13.239 & 0.106 & 9.932 & 0.216 \\
\hline LNG Europe [1] & $H_{0}: r \leq 1$ & 0.025 & 3.306 & 0.069 & 3.306 & 0.069 \\
\hline Henry Hub & $\mathrm{H}_{0}: r=0$ & 0.058 & 8.899 & 0.374 & 7.772 & 0.402 \\
\hline Brent [1] & $H_{0}: r \leq 1$ & 0.008 & 1.127 & 0.288 & 1.127 & 0.288 \\
\hline Brent & $\mathrm{H}_{0}: r=0$ & 0.066 & 10.690 & 0.231 & 8.773 & 0.305 \\
\hline Pipe US [2] & $H_{0}: r \leq 1$ & 0.014 & 1.916 & 0.166 & 1.916 & 0.166 \\
\hline Brent & $\mathrm{H}_{0}: \mathrm{r}=0$ & 0.349 & $55.020 * * *$ & 0.000 & $54.227 * * *$ & 0.000 \\
\hline LNG Europe [4] & $H_{0}: r \leq 1$ & 0.006 & 0.793 & 0.373 & 0.793 & 0.373 \\
\hline Brent & $\mathrm{H}_{0}: \mathrm{r}=0$ & 0.038 & 5.344 & 0.771 & 4.873 & 0.757 \\
\hline LNG Japan [7] & $H_{0}: r \leq 1$ & 0.003 & 0.471 & 0.492 & 0.471 & 0.492 \\
\hline WTI & $\mathrm{H}_{0}: r=0$ & 0.057 & 9.809 & 0.295 & 7.611 & 0.419 \\
\hline Henry Hub [2] & $H_{0}: r \leq 1$ & 0.017 & 2.197 & 0.138 & 2.197 & 0.138 \\
\hline WTI & $\mathrm{H}_{0}: r=0$ & 0.066 & 11.413 & 0.187 & 8.755 & 0.307 \\
\hline Pipe US [2] & $H_{0}: r \leq 1$ & 0.020 & 2.658 & 0.103 & 2.658 & 0.103 \\
\hline WTI & $\mathrm{H}_{0}: r=0$ & 0.305 & $46.870 * * *$ & 0.000 & $46.017 * * *$ & 0.000 \\
\hline LNG Europe [4] & $\mathrm{H}_{0}: r \leq 1$ & 0.006 & 0.852 & 0.355 & 0.852 & 0.355 \\
\hline WTI & $\mathrm{H}_{0}: \mathrm{r}=0$ & 0.042 & 5.712 & 0.729 & 5.318 & 0.701 \\
\hline LNG Japan [7] & $H_{0}: r \leq 1$ & 0.003 & 0.393 & 0.530 & 0.393 & 0.530 \\
\hline WTI & $\mathrm{H}_{0}: \mathrm{r}=0$ & 0.227 & $33.616 * * *$ & 0.000 & $32.580 * * *$ & 0.000 \\
\hline Pipe Europe [4] & $H_{0}: r \leq 1$ & 0.008 & 1.036 & 0.308 & 1.036 & 0.308 \\
\hline LNG Japan & $\mathrm{H}_{0}: r=0$ & 0.080 & 10.411 & 0.250 & 10.401 & 0.186 \\
\hline Henry Hub [6] & $\mathrm{H}_{0}: r \leq 1$ & 8.71E-05 & 0.010 & 0.917 & 0.010 & 0.917 \\
\hline LNG Japan & $\mathrm{H}_{0}: \mathrm{r}=0$ & 0.086 & 11.181 & 0.200 & 11.175 & 0.145 \\
\hline Pipe US [6] & $\mathrm{H}_{0}: r \leq 1$ & 5.54E-05 & 0.006 & 0.933 & 0.006 & 0.933 \\
\hline LNG Japan & $\mathrm{H}_{0}: \mathrm{r}=0$ & 0.047 & 6.832 & 0.597 & 6.095 & 0.601 \\
\hline LNG Europe [6] & $\mathrm{H}_{0}: \mathrm{r} \leq 1$ & 0.005 & 0.737 & 0.390 & 0.737 & 0.390 \\
\hline LNG Japan & $\mathrm{H}_{0}: r=0$ & 0.042 & 5.712 & 0.729 & 5.318 & 0.701 \\
\hline WTI [7] & $\mathrm{H}_{0}: r \leq 1$ & 0.003 & 0.393 & 0.530 & 0.393 & 0.530 \\
\hline Pipe US & $\mathrm{H}_{0}: \mathrm{r}=0$ & 0.092 & $15.036^{*}$ & 0.058 & $12.470 *$ & 0.094 \\
\hline LNG Europe [1] & $H_{0}: r \leq 1$ & 0.019 & 2.565 & 0.109 & 2.565 & 0.109 \\
\hline Pipe Europe & $\mathrm{H}_{0}: \mathrm{r}=0$ & 0.112 & $19.117 * *$ & 0.013 & $15.432 * *$ & 0.032 \\
\hline Henry Hub [1] & $\mathrm{H}_{0}: r \leq 1$ & 0.028 & $3.685^{*}$ & 0.054 & $3.685^{*}$ & 0.054 \\
\hline Pipe Europe & $\mathrm{H}_{0}: \mathrm{r}=0$ & 0.088 & 13.257 & 0.105 & 11.668 & 0.123 \\
\hline Pipe US [4] & $H_{0}: r \leq 1$ & 0.012 & 1.589 & 0.207 & 1.589 & 0.207 \\
\hline Pipe Europe & $\mathrm{H}_{0}: \mathrm{r}=0$ & 0.169 & $25.028 * * *$ & 0.0014 & $23.359 * * *$ & 0.0014 \\
\hline LNG Europe [4] & $H_{0}: r \leq 1$ & 0.013 & 1.669 & 0.196 & 1.669 & 0.196 \\
\hline Pipe Europe & $\mathrm{H}_{0}: \mathrm{r}=0$ & 0.246 & $36.710 * * *$ & 0.000 & $35.737 * * *$ & 0.000 \\
\hline Brent [4] & $\mathrm{H}_{0}: r \leq 1$ & 0.007 & 0.972 & 0.324 & 0.972 & 0.324 \\
\hline Pipe Europe & $\mathrm{H}_{0}: \mathrm{r}=0$ & 0.055 & 11.327 & 0.192 & 7.283 & 0.456 \\
\hline LNG Japan [3] & $H_{0}: r \leq 1$ & 0.031 & 4.043 & 0.044 & 4.043 & 0.044 \\
\hline
\end{tabular}

Notes: MacKinnon-Haug-Michelis (1999) p-values [ ] Lag Length. ***, ** and * denote statistical significance at $1 \%, 5 \%$ and $10 \%$ level of significance respectively. 


\section{Appendix 4: Pairwise Granger Causality Tests Results}

\begin{tabular}{|c|c|c|c|c|}
\hline Null Hypothesis & F-Statistic & Prob. & Lags & Causal Relation \\
\hline $\begin{array}{l}\text { PGUS does not granger cause HENRY HUB }(\mathrm{HH}) \\
\text { HENRY HUB does not granger cause PGUS }\end{array}$ & $\begin{array}{c}3.536 * * * \\
41.341 * * *\end{array}$ & $\begin{array}{l}0.009 \\
1 E-21\end{array}$ & 4 & $\mathrm{HH} \leftrightarrow \mathrm{PGUS}$ \\
\hline $\begin{array}{l}\text { LNGEUR does not granger cause HENRY HUB } \\
\text { HENRY HUB does not granger cause LNGEUR }\end{array}$ & $\begin{array}{c}0.875 \\
9.174 * * *\end{array}$ & $\begin{array}{l}0.351 \\
0.003\end{array}$ & 1 & $\mathrm{HH} \rightarrow$ LNGEUR \\
\hline $\begin{array}{l}\text { BRENT does not granger cause HENRY HUB } \\
\text { HENRY HUB does not granger cause BRENT }\end{array}$ & $\begin{array}{l}0.831 \\
0.266\end{array}$ & $\begin{array}{l}0.363 \\
0.606\end{array}$ & 1 & No causal relation \\
\hline $\begin{array}{l}\text { PGUS does not granger cause BRENT } \\
\text { BRENT does not granger cause PGUS }\end{array}$ & $\begin{array}{c}0.332 \\
2.449 *\end{array}$ & $\begin{array}{l}0.718 \\
0.090\end{array}$ & 2 & BRENT $\rightarrow$ PGUS \\
\hline $\begin{array}{l}\text { LNGEUR does not granger cause BRENT } \\
\text { BRENT does not granger cause LNGEUR }\end{array}$ & $\begin{array}{c}1.537 \\
21.777^{* * *}\end{array}$ & $\begin{array}{l}0.195 \\
2 \mathrm{E}-13\end{array}$ & 4 & BRENT $\rightarrow$ LNGEUR \\
\hline $\begin{array}{l}\text { LNGJAP does not granger cause BRENT } \\
\text { BRENT does not granger cause LNGJAP }\end{array}$ & $\begin{array}{c}0.713 \\
14.801 * * *\end{array}$ & $\begin{array}{l}0.660 \\
2 E-13\end{array}$ & 7 & BRENT $\rightarrow$ LNGJAP \\
\hline $\begin{array}{l}\text { HENRY HUB does not granger cause WTI } \\
\text { WTI does not granger cause HENRY HUB }\end{array}$ & $\begin{array}{l}0.178 \\
0.816\end{array}$ & $\begin{array}{l}0.837 \\
0.444\end{array}$ & 2 & No causal relation \\
\hline $\begin{array}{l}\text { PGUS does not granger cause WTI } \\
\text { WTI does not granger cause PGUS }\end{array}$ & $\begin{array}{l}0.379 \\
3.312\end{array}$ & $\begin{array}{l}0.684 \\
0.039\end{array}$ & 2 & No causal relation \\
\hline $\begin{array}{l}\text { LNGEUR does not granger cause WTI } \\
\text { WTI does not granger cause LNGEUR }\end{array}$ & $\begin{array}{c}1.901 \\
19.624 * * *\end{array}$ & $\begin{array}{l}0.114 \\
2 \mathrm{E}-12\end{array}$ & 4 & WTI $\rightarrow$ LNGEUR \\
\hline $\begin{array}{l}\text { LNGJAP does not granger cause WTI } \\
\text { WTI does not granger cause LNGJAP }\end{array}$ & $\begin{array}{c}0.717 \\
15.814 * * *\end{array}$ & $\begin{array}{l}0.657 \\
3 E-14\end{array}$ & 7 & WTI $\rightarrow$ LNGJAP \\
\hline $\begin{array}{l}\text { PGEUR does not granger cause WTI } \\
\text { WTI does not granger cause PGEUR }\end{array}$ & $\begin{array}{c}1.123 \\
11.472 * * *\end{array}$ & $\begin{array}{l}0.348 \\
7 \mathrm{E}-08\end{array}$ & 4 & WTI $\rightarrow$ PGEUR \\
\hline $\begin{array}{l}\text { LNGJAP does not granger cause HENRY HUB } \\
\text { HENRY HUB does not granger cause LNGJAP }\end{array}$ & $\begin{array}{c}1.611 \\
2.583^{* *}\end{array}$ & $\begin{array}{l}0.150 \\
0.022\end{array}$ & 6 & $\mathrm{HH} \rightarrow$ LNGJAP \\
\hline $\begin{array}{l}\text { PGUS does not granger cause LNGJAP } \\
\text { LNGJAP does not granger cause PGUS }\end{array}$ & $\begin{array}{c}1.599 \\
2.571 * *\end{array}$ & $\begin{array}{l}0.153 \\
0.022\end{array}$ & 6 & LNGJAP $\rightarrow$ PGUS \\
\hline $\begin{array}{l}\text { LNGEUR does not granger cause LNGJAP } \\
\text { LNGJAP does not granger cause LNGEUR }\end{array}$ & $\begin{array}{l}3.135 * * * \\
9.102 * * *\end{array}$ & $\begin{array}{l}0.007 \\
4 \mathrm{E}-08\end{array}$ & 6 & LNGJAP $\leftrightarrow$ LNGEUR \\
\hline $\begin{array}{l}\text { WTI does not granger cause LNGJAP } \\
\text { LNGJAP does not granger cause WTI }\end{array}$ & $\begin{array}{l}15.814^{* * *} \\
0.717^{*}\end{array}$ & $\begin{array}{l}3 \mathrm{E}-14 \\
0.717\end{array}$ & 7 & $\mathrm{WTI} \rightarrow$ LNGJAP \\
\hline $\begin{array}{l}\text { LNGJAP does not granger cause BRENT } \\
\text { BRENT does not granger cause LNGJAP }\end{array}$ & $\begin{array}{c}0.276 \\
3.968 * *\end{array}$ & $\begin{array}{l}0.599 \\
0.048\end{array}$ & 1 & BRENT $\rightarrow$ LNGJAP \\
\hline $\begin{array}{l}\text { HENRY HUB does not granger cause PGEUR } \\
\text { PGEUR does not granger cause HENRY HUB }\end{array}$ & $\begin{array}{l}11.677^{* * * *} \\
0.379\end{array}$ & $\begin{array}{c}0.0009 \\
0.539\end{array}$ & 1 & $\mathrm{HH} \rightarrow \mathrm{PGEUR}$ \\
\hline $\begin{array}{l}\text { PGUS does not granger cause PGEUR } \\
\text { PGEUR does not granger cause PGUS }\end{array}$ & $\begin{array}{c}2.444^{*} \\
1.186 \\
\end{array}$ & $\begin{array}{c}0.0503 \\
0.320\end{array}$ & 4 & PGUS $\rightarrow$ PGEUR \\
\hline $\begin{array}{l}\text { LNGEUR does not granger cause PGEUR } \\
\text { PGEUR does not granger cause LNGEUR }\end{array}$ & $\begin{array}{l}5.340 * * * \\
6.416 * * *\end{array}$ & $\begin{array}{l}0.0005 \\
0.0001\end{array}$ & 4 & LNGJAP $\leftrightarrow B R E N T$ \\
\hline $\begin{array}{l}\text { BRENT does not granger cause PGEUR } \\
\text { PGEUR does not granger cause BRENT }\end{array}$ & $\begin{array}{c}12.087 * * * \\
1.031\end{array}$ & $\begin{array}{l}3 \mathrm{E}-08 \\
0.394\end{array}$ & 4 & BRENT $\rightarrow$ PGEUR \\
\hline $\begin{array}{l}\text { PGEUR does not granger cause LNGJAP } \\
\text { LNGJAP does not granger cause PGEUR }\end{array}$ & $\begin{array}{c}1.661 \\
4.747^{* * *}\end{array}$ & $\begin{array}{l}0.179 \\
0.003\end{array}$ & 3 & LNGJAP $\rightarrow$ PGEUR \\
\hline
\end{tabular}

Note: $* * * * *$ and $*$ denote statistical significance at $1 \%, 5 \%$ and $10 \%$ level of significance respectively. 